\title{
Evaporation-driven deposition of $\mathrm{WO}_{3}$ thin films from organic-additive-free aqueous solutions by low-speed dip coating and their photoelectrochemical properties
}

Hiroaki Uchiyama*, Seishirou Igarashi and Hiromitsu Kozuka

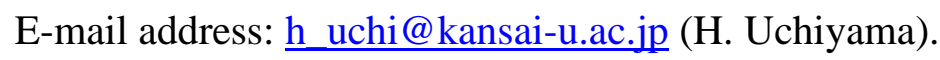

Table S1. Thickness of the precursor films deposited on FTO glass substrates, and cracking after the heat treatment ${ }^{* 1}$

\begin{tabular}{|c|c|c|c|}
\hline \multicolumn{2}{|c|}{ Coating conditions } & \multirow{2}{*}{$\begin{array}{c}\text { Thickness of } \\
\text { precursor films / } \\
\mathrm{nm}^{* 2}\end{array}$} & \multirow{2}{*}{$\begin{array}{c}\text { Cracking after } \\
\text { the heat treatment }^{* 3}\end{array}$} \\
\hline $\begin{array}{l}\text { Substrate withdrawal speed / } \mathrm{cm} \\
\qquad \min ^{-1}\end{array}$ & $\begin{array}{l}\text { Coating temperature / } \\
{ }^{\circ} \mathrm{C}\end{array}$ & & \\
\hline 0.02 & 60 & $260 \pm 4$ & Yes \\
\hline 0.03 & 60 & $95 \pm 39$ & No \\
\hline 0.03 & 30 & $88 \pm 18$ & No \\
\hline
\end{tabular}

*1 The precursor films were obtained from the coating solutions of $x=11.4 \mathrm{mM}$ containing the $\mathrm{HCl}$ solutions of $\mathrm{pH} 1.5$.

*2 The thickness was measured for the precursor films dried at $100{ }^{\circ} \mathrm{C}$ for $12 \mathrm{~h}$.

$* 3$ The heat treatment of the precursor films was done at $500{ }^{\circ} \mathrm{C}$ for $10 \mathrm{~min}$ in air. 

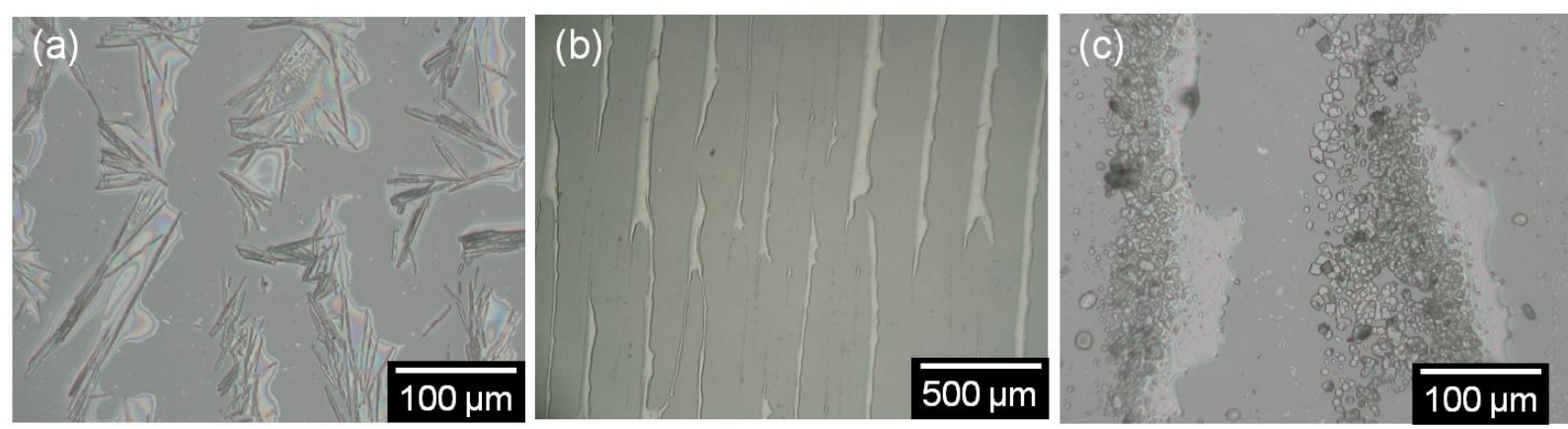

Supporting Information Figure S1. Optical micrographs of the $\mathrm{WO}_{3}$ precursors obtained from the coating solutions of $x=3.75 \mathrm{mM}$ containing the $\mathrm{HCl}$ solutions of $\mathrm{pH} 1.8$ (a), 2.0 (b) and 2.2 (c) by dip coating at $0.02 \mathrm{~cm} \mathrm{~min}^{-1}$ in a thermostatic oven at $60{ }^{\circ} \mathrm{C}$. 


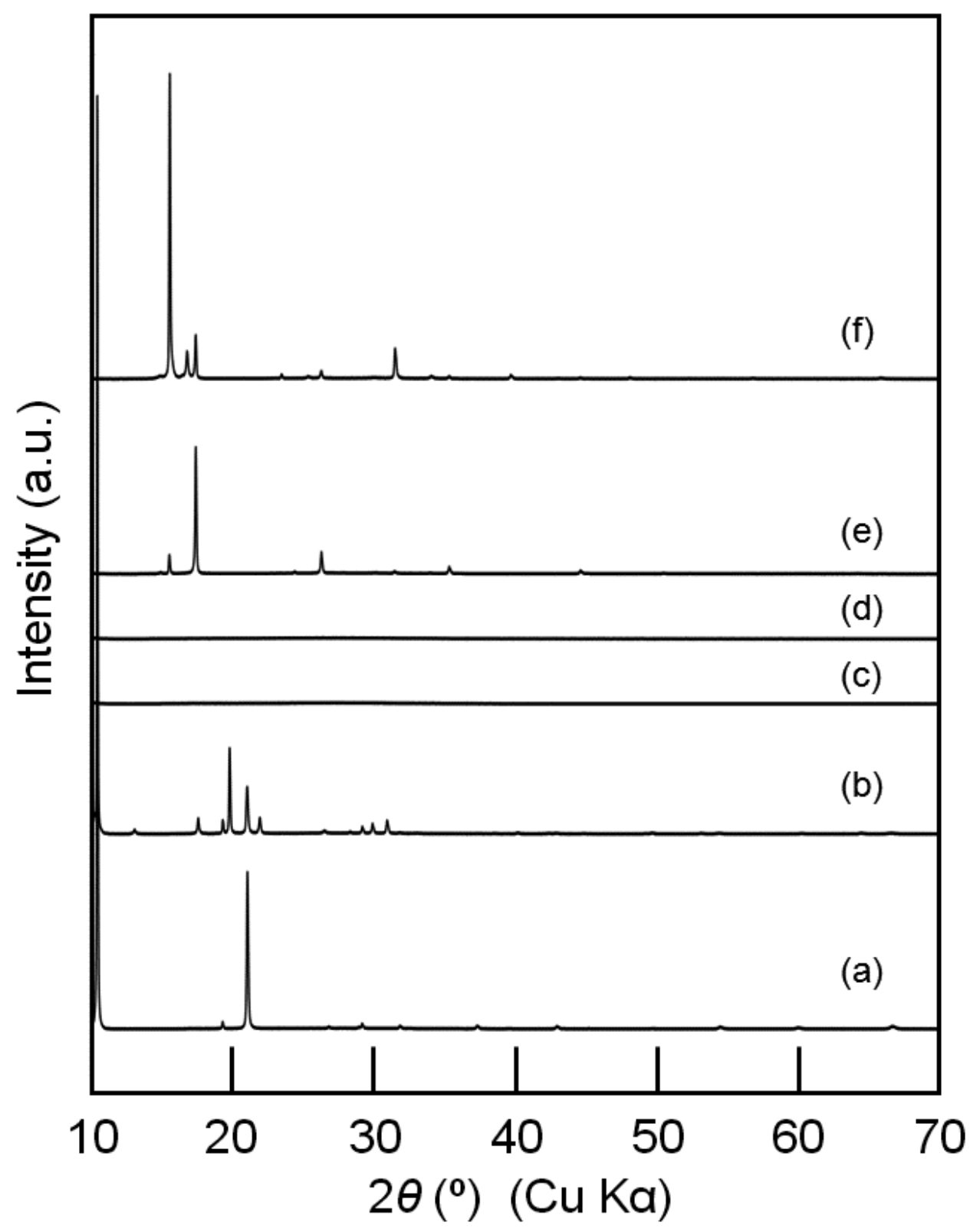

Supporting Information Figure S2. XRD patterns of the $\mathrm{WO}_{3}$ precursors obtained from the coating solutions of $x=7.57 \mathrm{mM}$ containing the $\mathrm{HCl}$ solutions of $\mathrm{pH} 1.2$ (a), 1.4 (b), 1.6 (c), 1.7 (d), 1.8 (e) and 2.0 (f) by dip coating at $0.02 \mathrm{~cm} \mathrm{~min}^{-1}$ in a thermostatic oven at $60^{\circ} \mathrm{C}$. 


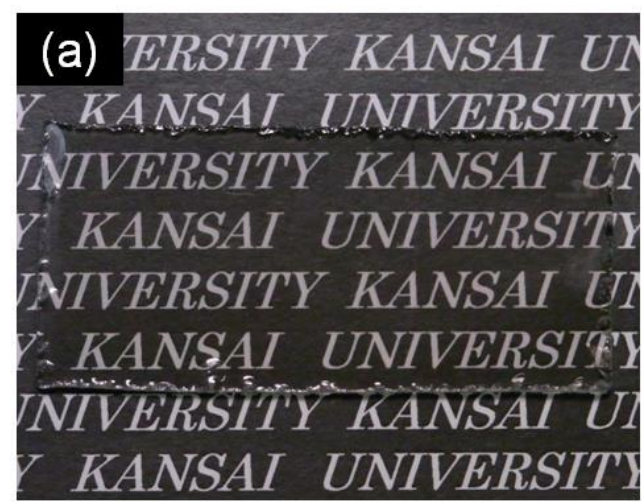

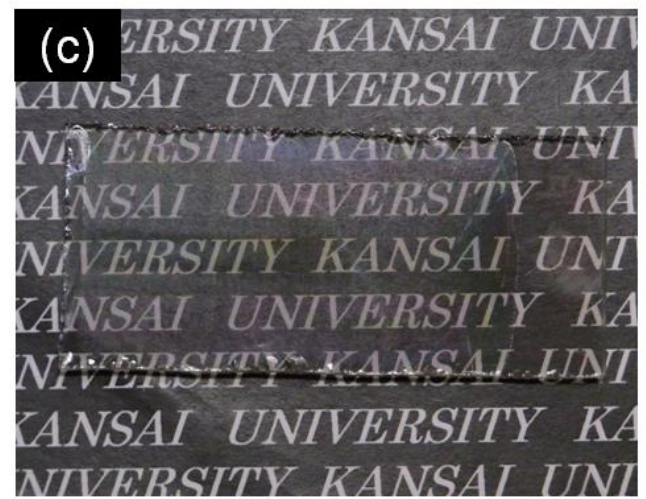

(e) KANSAI UNIVERSI I JANJIRSITV KANSAI IY KANSAI UNWRRSI! I. UNIVERSITY KANSAI 1.Y KANSAI UNIVERSI I UNDVERSTTY KANSAI TY KANSAI UNIVERSI I UNIVERSITY KANSAI

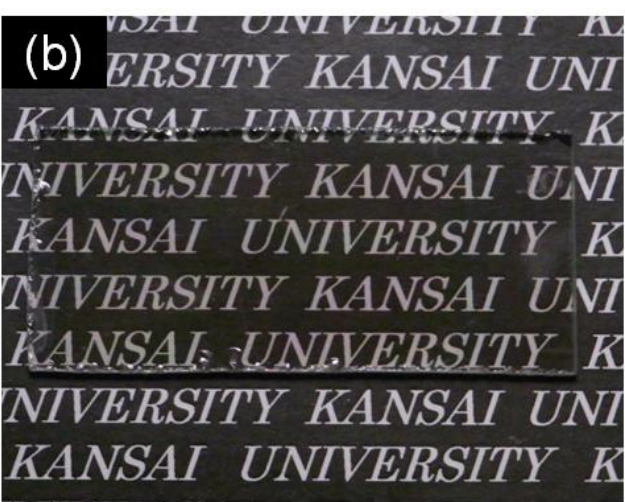

(d) IERSITY KANSAI U $Y$ KATSAT ENTHEDSTIY UIVIVERSTY KANSAI U 'Y KANSAI UNIVERSITY UNIVERSITY KANSAI UL $Y$ KALASAL UNIVERSITY UNIVERSITY KANSAI U Y KANSAI UNIVERSITY

(f) INASAI UNIVERSITY
UAIUBRSITY KANSAI.
I KANSAI UNIVERSITY
UNIVERSITY KANSAI
Y KANSAI UNIVERSITY
INIVERSITY KANSAI
Y KANSAI UNIVERSITY
UNIVERSITY KANSAI

(g) VERSITY KANSAI L
Y KIISAI UNTIWRSIT
UNIVERSITY KANSAI
Y KANSAI UNIVERSIT
UNIVERSITY KANSAI
Y KANSAI UNIVERSIT
UNIVERSITY KANSAI
Y KANSAI UNIVERSIT

Supporting Information Figure S3. Optical micrographs of the precursor film (a) and heat-treated films obtained at 200 (b), 300 (c), 400 (d), 500 (e), 600 (f) and 700 (g) ${ }^{\circ} \mathrm{C}$. 